\title{
Concubinage in the Polish Tax Law
}

\author{
Aleksy Goettel
}

ABSTRACT The main goal of this study is to assess whether, and if so, how the tax policy is implemented in Poland in relation to informal partnerships. The justification for conducting research in this area is the growing number of such relationships and the demands formulated by the public on the principles of taxation of cohabitants. The study analyzes not only taxes on natural persons, but also the provisions governing the principles of tax liability. The research shows that while pro-family tax policy is implemented on a fairly large scale in Poland, it does not apply to cohabitants. In principle, cohabitants do not have the right to any preferential taxation rules, above all tax reliefs and exemptions. Moreover, the analysis of the research material clearly indicates that staying in cohabitation can even aggravate the situation of a cohabitant under tax law (which can be seen perfectly well on the example of a cohabitant's liability for his partner's taxes). On the basis of a critical analysis of the Polish tax law provisions, the general thesis has been formulated that the situation of cohabitants is affected by deep asymmetry, because on the one hand the legislator uses cohabitation to improve the allocation of public revenues, but on the other hand it does not include cohabitants with profamily tax policy (although cohabitation is very similar to marriage). The study includes certain demands on the legislator, thanks to which it is possible to cover cohabitants by pro-family tax policy.

KEY WORDS: $\quad$ Tax, tax policy, tax law, tax exemptions, tax reliefs, cohabitation, cohabitants, concubinage.

JEL Classification: K34, K36.

University of Economics and Human Sciences in Warsaw

\section{Introduction}

There has been a steady increase in the number of informal partnerships in this century. In Poland, for instance, although not on the same scale as in most countries of the European Union, this trend is also visible (Ryznar \& Stepien-Sporek, 2019). Regardless of why an increasing number of people choose to stay in cohabitation with their partner, it is important that this phenomenon has a significant impact on legal systems of individual countries. An extremely important manifestation of the growing importance of informal relationships are - undertaken by many countries (e.g., Norway, Sweden, Ireland, Italy, Lithuania) - successful attempts

Correspondence concerning this article should be addressed to: Aleksy Goettel University of Economics and Human Sciences in Warsaw, Okopowa 59, 01-043 Warsaw, Poland

E-mail: a.goettel@vizja.pl (more or less) to regulate comprehensively the issue of cohabitation in a single legal act (Barlow, 2004; Skuza, 2020; Pawliczak, 2020). It should be made clear, however, that cohabitation also affects the legal systems of those countries, where legal acts - specifically dedicated to cohabitants - have not been adopted. In Poland, despite the attempts made, no law that would in any way regulate informal partnerships has been passed (Ryznar \& Stepien-Sporek, 2019; Zaborowska, 2015). However, as stated above, the cohabitation is not neutral from the point of view of the Polish legal order. It may seem that since cohabitation has not been regulated in the Polish family and civil law, its influence on the legal system must concern almost exclusively public law. Therefore, it is worth asking whether cohabitation, as a significant social phenomenon, is of any importance from the point of view of tax law? 
The answer to this question (which is the primary objective of this article) is extremely important, since taxes, as the main form of compulsory public tributes in most developed countries, have a significant impact on the social situation and determine the numerous actions (family, economic, property or professional) undertaken in daily life.

Let us therefore repeat, that the purpose of this analysis (based on formal legal and dogmatic approach) is an attempt to answer the question whether the State's tax policy includes informal partnerships. Assuming that, through an analysis, we can answer to the above question in the affirmative, another question becomes relevant - whether cohabitation is beneficial for the informal partners (especially in comparison to the spouses) in the light of Polish tax law? The considerations, which include the attempt to remove the aforementioned doubts, are to enable formulating possible postulates to the legislator. It is important, after all, for tax policy using tax law as a tool, not only to be effective, but also to be based on properly formulated assumptions taking into account the changes taking place in the modern world.

\section{Concubinage and the Polish law - Terminology Remarks}

As explained above, there is no "comprehensive" legal act in the Polish legal system, that regulates the phenomenon of cohabitation. There is even no single act in the Polish legal regime which makes subject to its provision issues of informal relationships or regulates the legal status of cohabitants, the property relations between them, the question of succession after an informal partner, etc. We also do not find the definition of cohabitation in the applicable provisions of the Polish family, civil and public law. Tax law makes no exception in this respect. It must therefore be emphasized that for the time being the cohabitation is not a legal concept (the definition of cohabitation has not been determined by law), whereas being in an informal relationship is not so much a legal relationship but a certain social fact (Hahlo, 1972). It is already worth noting that the provisions of different branches of law generally do not use the terms " concubinage" (pol. "konkubinat") and "cohabitation" (pol. "kohabitacja") to determine the status of a couple living together. The legislature rather describes concubinage (cohabitation) as a union of two people by identifying its certain characteristics, but without the use of the word "cohabitation" and "concubinage". Since the provisions of different branches of law refer (albeit under different names) to concubinage, it is worth trying to determine what concubinage actually is. It is generally accepted that cohabitation is an informal, monogamous relationship - essentially - of a woman and a man, who live together and run the household, and between whom there is a personal (emotional) relationship. In this respect, cohabitation is a partnership similar to marriage. It can be said that primarily the lack of formalization distinguishes cohabitation from marriage, although it must be remembered that the possible breakdown of the emotional or physical bond between the spouses does not, in itself, result in the termination of marriage (Mazur, 1997). Marriage, unlike cohabitation, is a legal relationship which not only arises but also ceases in the procedures in force, not in connection with the actual breakdown of ties (Stojanowska, 1988). By the way, only marriage (when it comes to partnerships) is subject to constitutional protection (SiostrzonekSergiel, 2015). Pursuant to Article 18 of the Polish Constitution of 1997, marriage as a relationship between a woman and a man, family, motherhood and parenthood are under the protection and care of the Republic of Poland. The question, of course, is whether the formalization of cohabitation (which is possible in certain countries) by, for example, the registration with the relevant authority, does not cause such a relationship which ceases to be actual cohabitation? There is a view that in such a case a "registered concubinage" is created, which is no longer a factual relationship, but a legal relationship which produces (depending on the solutions adopted) a number of legal implications (e.g. in the area of the property).

One of the more difficult concerns to resolve (about understanding the concept of "cohabitation") refers to the problem of homosexual relationships (Martin \& Thery, 2001). It should be emphasized that this matter proved to be extremely important in tax practice, since the Polish administrative courts (which shall be discussed in more detail later) struggled with the assessment of "same-sex concubines" for the purposes 
of settling specific tax cases. On the one hand, there is a fairly well-established belief that concubinage, because of its similarity to marriage (understood as a union between a man and a woman), cannot form same-sex persons. Proponents of this view often refer to the tradition and the original role of partnerships. On the other hand, there is a growing trend of moving away from defining cohabitation on the basis of the gender criterion. The literature draws attention to the fact that relations typical of cohabitation (in the sense adopted above) can be formed between persons of the same sex (Garlicki, 2019).

\section{Situation of Cohabitants in the Light of Tax Policy (Theoretical Aspect)}

Tax policy as one of the crucial elements of the fiscal policy, consists in undertaking (primarily by the State) well-thought-out actions regarding the shape of the tax system and its functioning in order to achieve the intended social and economic goals (Święch, 2009; Dziemianowicz, 2019). Presenting all areas of activity in which the tax policy is or may be conducted is naturally neither appropriate nor possible in this paper. However, it seems necessary - for the purpose of the analysis - to try to determine what tax policy can be or should be applied to cohabitation. It appears that the tax policy, taking into account the existence of informal partnerships, can take various forms and purposes. It is therefore worth taking a closer look at this issue.

Firstly, the State may, by means of tax instruments, affect, for example, the perception of cohabitation by society, making such a form of partnership more or less attractive to citizens (Fox, 2017). It mainly depends on the tax policy objective adopted. The State, of course, is able to use taxes to discourage partners from staying in cohabitation. It should be noted once again that cohabitation is a kind of partnership similar to marriage. At the same time (as already mentioned) marriage is subject to constitutional protection, which makes the State a pro-marriage policy applying quite a number of tax instruments in this regard. Generally speaking, this policy consists of applying tax preferences (tax reliefs and exemptions) resulting in reduction or abolition of fiscal burdens (Szczepanska, 2013). However, the promotion of marriage by the State as the preferred form of partnership should not eliminate the use of tax instruments to support other types of partnerships.
After all, it cannot be disputed that the concubines form a family community (Tărchilă, 2017). If, therefore, the State supports marriage through numerous tax preferences, why should it not do so in relation to the similar form of partnership like cohabitation. Generally, the tax policy should align - from the tax law point of view - the legal situation of cohabitans and spouses, for example by granting informal partners the right to joint taxation or by exempting them from taxation of donations and inheritances.

In view of the specific characteristics of the individual taxes involved in the tax system, it is necessary to consider whether all of them are equally suitable for the tax policy in relation to cohabitation.

Certainly, the impact of income taxation on cohabitation can only be analyzed on the basis of taxes on natural persons. It is difficult to imagine a pro-family corporate income tax policy, since the tax is not levied on natural persons at all.

It is clear that taxes on individuals' incomes form a very effective tax policy tool for cohabitation. These taxes are direct, which means that they can be adapted to the taxpayer's personal situation (Sosnowski, 2012; Małecka 2005). Tax doctrine often emphasizes that taxes on individuals' income should take into account the family situation of the taxpayer, his health status (and his family members), issues related to education, etc. Theoretically, there are no obstacles to apply tax preferences in the income tax of individuals, which allow partners who live together to reduce the fiscal burden.

In the framework of the tax policy aimed at supporting cohabitation, it is possible, or even desirable, to use various forms of taxation of free transfers of assets. The specific nature of free transfer of assets (mainly inheritances and donations) means that they usually take place in family relationships, and thus also between cohabiting people. The literature study indicates that any intra-family transfers of property free of charge should be tax-free or, alternatively, less taxed in relation to benefits provided free of charge outside family relationships. It is pointed out that one of the reasons why unpaid intra-family benefits should be taxed in a preferential way is that the family's assets are often the result of the work of all its members.

Of course, the above-mentioned consideration should not lead to the conclusion that it is not possible 
to pursue a cohabitant-friendly tax policy in respect of other taxes (e.g., turnover taxes or property taxes). However, it appears that only in the case of taxation of the personal income of cohabitants and free transfers of assets between them, such a tax policy is particularly justified. For example, on the basis of taxation of professional economic turnover by means of value added tax (VAT), it is generally not easy to pursue a family tax policy, since the tax is indirect (which makes it difficult to assess the family situation of the person bearing the tax burden, who is the purchaser of the goods or services).

Secondly, it should be noted that, since cohabitation is a partnership imitating marriage, it can theoretically be an instrument for increasing the efficiency of tax enforcement. That assertion stems from the fact that, within the tax system, many States create special legal mechanisms by which other persons bear responsibility for the tax, next to or instead of the taxpayer. A key problem in this case is to establish criteria by which it would be possible to determine the group of such persons. These criteria include, and it is a common practice, the existence of property and personal relationships between the taxpayer and the person liable instead of or jointly with the taxpayer. This means that the taxpayer's cohabitant, as a person remaining undoubtedly in a close personal relationship,(also of economic nature), can potentially be classified as the persons responsible for his partner's taxes.

Thirdly, notwithstanding the above (basic) forms of the use of cohabitation under tax policy, it is possible to regulate informal partnerships in tax legislation on other issues. There is no doubt that marriage may also be an important point of reference in this case. Certainly, some tax law institutions adopted to regulate marital issues can or indeed should be applied to cohabitants, for example, the tax procedure, tax payment methods, etc.

\section{Situation of Cohabitants under the Polish Tax System}

In the light of the above analysis, it is worth asking the fundamental question - to what extent, if any, the Polish legislature has shaped the tax policy in relation to cohabitation? The attempt to answer this question should be preceded by the provision, that remarks formulated in this section shall solely focus on the tax sys- tem (other issues shall be discussed later).

In the first place, it is worth examining the tax on personal income of individuals, because (as explained) this tax is particularly useful from the point of view of family tax policy. The personal income tax applied in Poland has many features of pro-family tax. The rules governing this tribute allow for a significant reduction or abolition of fiscal burdens through numerous tax reliefs and exemptions (Rekas, 2015). The most important solutions in this regard include: exclusion from taxation of benefits to meet the needs of the family (as referred to in Article 27 of the Family and Guardianship Code of 1964, both spouses are obliged, each according to their strength, earning and financial capacity, to contribute towards meeting the need of the family founded by their marriage), joint taxation of spouses (particularly profitable for spouses of large disparity of income, because final amount of tax is the result of adding their incomes, then dividing the amount into two and finally - multiplying the last amount by two; however spouses of identical incomes basically never benefit from joint taxation, nevertheless this institution is defined in doctrine of tax law as tax preference), preferential rules on the taxation of single parents (joint taxation of incomes of a single parent and a child) and numerous tax exemptions, some of which are granted for family reasons, for example the maintenance for children under 25 years old (Kędzierska-Szczepaniak, 2015). The analysis of the provisions governing those tax preferences proves undoubtedly that there is not at least one preference in Polish income tax which would be expressis verbis established for the taxable person living in cohabitation (some of tax preferences, like exemption from income tax of maintenance for a child, may also be applied to couples living in cohabitation but this preference was established for other reasons than the fact of living in cohabitation). It follows that, as regards income tax, the tax policy aimed at supporting informal partnerships is not pursued. Perhaps the legislature considers that cohabitation, although it is an expression of the existence of family ties, is not a "solid" partnership enough to cover it with preferential tax policy.

Some concerns about granting tax preferences cohabitants may also arise from difficulties in verifying the existence of cohabitation. This, of course, should not preclude the cohabitant's right to certain tax pref- 
erences, although proving that the taxpayer remains in an informal relationship may sometimes be actually difficult. The difference between spouses and cohabitants - as far as the State's tax policy is concerned - is probably most evident from the point of view of the joint taxation of the spouses' income. This preference, commonly used in many countries, is based on the concept of economic unity of the spouses (Knauer, 1998). The idea of joint taxation of spouses is therefore to treat the spouses as if they were a single entity in economic relations. Concubines, and this remark does not require a special explanation, also form an economic community. As a general rule, they live together and jointly run a household. This circumstance provides sufficient grounds for assuming that the tax preference in the form of joint income taxation should also apply in their case. However, under Polish regulations, joint taxation is only granted to spouses in the joint property of husband and wife (Nowak, 2017). So, for example, the spouses who have chosen to establish the system of separate estates by marriage settlement will not be entitled to that tax credit. However, this restriction has been criticized in the doctrine of tax law. For axiological reasons, all spouses should have the right to joint taxation, regardless the statutory or contractual system of property rights, similarly to concubines.

The problem of taxation of gratuitous transfers of assets between persons living in informal relationships should then be examined. Since their relationship is of a very similar nature to the relationship of the spouses, it is worth analyzing whether, for example, the donations made by cohabitants to their partners benefit from preferential tax rules. Free acquisition of property or property rights by natural persons is subject to inheritance and endowment tax in Poland. That tax has also numerous characteristics by which free increments of property made between family members are either taxed on preferential terms or are not taxable at all (Panek, 2018). The effect of pro-family taxation in the inheritance and endowment tax results from the division of taxpayers into three groups, with different tax rates for each of these groups. The most preferential taxation refers to persons belonging to the first tax group, which includes the spouse, descendants, ascendants, stepson, son-in-law, daughter-in-law, siblings, stepfather, stepmother and in-laws. The second tax group (which has less favorable rates) was classified as ascending siblings, siblings of parents, spouses and spouses of stepdaughters, sibling spouses and siblings of spouses, spouses of other ascenders. The highest rates apply in a third group, referring to "other purchasers". It is therefore clear that the concept of dividing taxpayers into three groups makes the burden of tax dependent on the nature of family ties. So, for example, receiving a donation of a certain value from the spouse results in the payment of a lower tax than donation from received from the niece. What is then the situation of the cohabitants against this background? Of course, informal partners are treated as "other purchasers", which means that the legislator applies to them the same rates as to other people outside the family circle. Meanwhile, the cohabitants - because of their bond - not only establish donations among themselves, but also inherit from one another, although only on the basis of the will, because pursuant to the Polish inheritance law the cohabitants do not inherit from each other by virtue of the law (Jaworski, 2012).

The situation of the cohabitants is similar in terms of tax exemptions in the inheritance and endowment tax. One of the most important instruments of pro-family policy in the Polish tax system is the exemption where (after meeting the conditions set out in the law) the acquisition of property or property rights by a spouse, descendants, ascendants, stepchildren, siblings, stepfather and stepmother is exempt from tax.

This preference is not free from controversy. Doctrine have often emphasized that, as a result of its implementation, the budgetary revenues of municipalities have significantly decreased (inheritance and donation tax does not accrue the State budget, but only municipal budgets). From the point of view of this analysis, however, another issue deserves attention. Since the concubines did not find themselves among those entitled to benefit from the exemption under consideration, for example the donation made by a cohabitant to his partner is neither to be exempt from tax nor taxed at preferential tax rates. One important remark should be made here. This is a tax exemption under which taxfree entitlements to a savings and credit account are acquired by a person actually in a joint marriage with the holder of a savings and credit account at the housing register, provided that the funds accumulated in that account are allocated for residential purposes. Without going into the details of the above regulation, it should 
be clarified that although the concubines were included there as entitled to benefit from that preference, it did not result in the tax policy adopted in this case but was a consequence of granting informal partners (under other provisions) the right to transfer rights to a savings and credit account. Of course, the legislature may have omitted the cohabitants in terms of the preferences at issue, but apparently it considered too controversial.

In summing up this part of the considerations, it should be noted that the cases discussed above regarding omission of cohabitation under pro-family tax policy are of particular importance. They are most clearly indicative of the attitude of the legislator, which does not see the need for the inclusion of the cohabitants with a preferential tax model. It is worth adding that other taxes that create the tax system in Poland do not take into account informal partnerships, although (as already explained) this seems more understandable. The specificity of the subject of taxation or the technique for collecting turnover and property taxes makes them not specifically suitable for the conduct of pro-family tax policies. For these reasons, not only the concubines, but even the spouses were not specifically treated on the basis of the taxation of turnover (with some exceptions) and property.

\section{Concubinage in the Light of Tax Liability}

As has already been tentatively explained, the existence of a personal bond between cohabitants can theoretically form the basis for liability of each of them for the partner's taxes. The rules under which the cohabitant is responsible for his partner's taxes must, of course, differ from the concept of liability of the taxpayer's spouse who he remains in a joint marital property regime with. These differences arise from the fact that the concubines cannot base their property relationships on the joint property regime (which is reserved only to spouses), so the tax liability of each informal partner must be limited to his personal (individual) property only. From the point of view of the rules of tax liability, the cohabitant's situation may therefore be similar to that of the spouse, but only if there is a separate property regime between the spouses.

The tax liability of the taxpayer's cohabitant is the result of establishing a wide range of persons, classi- fied as "family members" of the taxpayer. The provisions governing this issue provides that (in addition to the descendants, ascendants, siblings, descendants' spouses and, after further conditions, the taxpayer's spouses) it is the taxpayer's cohabitant, who - as a "family member" - is liable jointly with the taxpayer (only if the taxpayer conducted a business activity and the tax arrears resulted from this activity and additionally arose in the period in which the cohabiting partner was constantly cooperating with the taxpayer in performing it, gaining benefits from his activity). It should be clarified that the abovementioned provision did not use the term "concubinage" but used the phrase "the person remaining with the taxpayer in actual life". This solution, as already mentioned, is widely used, not only in tax law. The wording "in actual life" clearly emphasized that, from the point of view of the cohabitant's liability, it is essential that there is an actual existence of a partnership between the cohabitant and the taxpayer. It is often difficult to determine whether certain persons actually form a partnership, but apparently the legislature has considered that the protection of public revenue is a matter of great importance. The fact is, however, that the legislature has decided to introduce certain restrictions on the type of liability in question (Szlęzak, 1991). First, the liability of family members is at stake only if the recovery of the tax on the taxpayer's assets is in whole or in part impossible. Secondly, the condition for the tax liability of a family member is to carry out an economic activity with the taxable person. In such a situation, the liability of the taxpayer's cohabitant covers only the tax arrears relating to the above activity and the duration of the activity. This shows a certain compromise between the care of public income and the well-being of the taxpayer's family members, including cohabitants. The fact that marriage laws do not apply to cohabitation, however, has quite serious consequences. On the one hand, cohabitation facilitates tax enforcement, but on the other hand the situation of cohabitants may worsen. In the case-law of the administrative courts, it is taken that, since the condition of the cohabitant's tax liability is the finding of certain facts and not considering their legal situation, the type of liability at issue must also apply to homosexual cohabitants. 


\section{Impact of Other Tax Laws on Cohabitation}

When analyzing the next problem, it is worth starting with the question whether the specific bond that unites informal partners can be relevant to other tax law issues? An analysis of the tax rules shows that there are at least a few legal structures for which the cohabitation should not be indifferent.

One of the issues that needs to be explored is the problem of excluding an employee of the tax authority because of the relationship existing between him and the taxpayer whose case is to be recognized by the employee. Moreover, that question does not concern only tax law. It is a universally accepted standard that, in the various legal procedures (criminal, civil, administrative), there is an exemption of a worker whose objectivity in the resolution of the case raises doubts (Daniluk, 2015). Very importantly, it is rightly considered that the lack of impartiality may concern cohabitants. For this reason, appropriate arrangements are being established to prevent cases relating to informal partners from being dealt with by administrative or judicial staff. This problem has also been regulated in the rules governing the tax procedure. It follows from those provisions that the case in question should not be decided by the spouse of the taxable person, since for understandable reasons, there may be concerns as to his objectivity. The problem, however, is that tax legislation does not treat cohabitation as a negative circumstance affecting the objectivity of an employee of the tax authority. In fact, specific provisions stipulate that an employee of a tax authority is exempted if they are in a legal relationship with the taxpayer so the outcome of the case may affect their rights or obligations. However, as it has been pointed out on several occasions, cohabitation is a factual relationship in Poland, not a legal relationship. Therefore, on the basis of the mere existence of an informal partnership between cohabitants, an employee of the tax authority cannot be excluded. Of course, it can happen if, regardless of cohabitation, a tax administration employee will combine a legal relationship with the partner (e.g., co-ownership of the house). If then there is an exclusion of an employee of the tax authority from the recognition of the case, it is solely because of the legal relationship, not because of the actual partnerships and the concerns relating to objectivity. It seems clear that the tax legislature should properly regulate this issue and therefore regard the cohabitation as the reason for excluding a staff member of the tax authority from examining of the case concerning his informal partner. Moreover, the need for that exclusion must also continue after the end of an informal relationship, as is the case on the basis of the former spouses.

It also appears that, in a slightly more favorable way to the cohabiting, the legislature could regulate the issue of another person's replacement for the payment of tax. In order to facilitate the implementation of tax payments, the legislature introduced provisions under which - instead of the taxpayer - tax can be paid by any person, but only up to an amount not exceeding PLN 1000. However, the taxpayer's spouse, his descendants, stepdaughter, siblings, stepfather and stepmother are treated in a special way, as they can pay tax regardless of the amount. Of course, such a solution is justified, since no limits on the immediate family of the taxpayer is an expression of a legitimate, familyfriendly tax policy. However, one again it is difficult to understand why, for axiological reasons, the legislature has not treated concubinage on an equal footing with marriage.

\section{Summary}

On the basis of the presented analysis, the following conclusions may be drawn up and, therefore, answers to the questions asked in the introduction to this article.

The problem of cohabitation as such has been noticed by the Polish tax legislature. However, it is difficult to consider the tax policy aimed at supporting informal partnerships coherent and coordinated. To some extent, this condition should be treated with understanding. The legislator probably takes the view that in comparison with spouses, informal partnerships still have too little social importance to regulate them (in tax law) more comprehensively. Although it must be remembered that in relation to cohabitants it is not always possible to apply solutions enacted for institution of matrimony (Herring, 2014). This is due to a fact that informal partners do not remain in property relations based on a joint property regime, which is reserved for spouses.

Arguably, the most characteristic feature (and at 
the same time a drawback) of the provisions of the Polish tax law concerning informal partnerships is the lack of adequate sustainability of the private interest of taxpayers and the interest of the State. The fundamental problem is that the State treats cohabitation as an instrument to protect budget revenue and therefore does not cover it with a tax-based family policy. With one exception (discussed in the study), people living in informal partnerships cannot benefit from any tax reliefs or exemptions. This is of particular importance in terms of income tax (where the cohabitants were not granted the right to joint taxation) and inheritance and endowment tax (in which the donation received from the partner or the inheritance acquired from the partner is taxed on non-preferential rules). At this point it is worth noting that in some cases living in concubinage entails unexpected risks on tax grounds. Mass media have repeatedly informed of the decisions of the tax authorities, in the light of which the residence by one of the cohabitants in an apartment belonging to another partner is treated as a benefit subject to income tax.

One obstacle to granting tax preferences to cohabitants results from difficulties of clearly specifying whether certain individuals actually remain in an informal relationship. However, it should be borne in mind that identical doubts may arise under the cohabitant's tax liability (as mentioned above). However, this circumstance apparently did not prove particularly relevant since the legislature assumed the responsibility of the taxpayer's cohabitant. There is no convincing reason why the potential difficulties in proving living together in cohabitation should result in the exclusion of cohabitants from the scope of pro-family tax policy. Perhaps the tax policy on cohabitants should be based on some compromise. To suggest that the situation of cohabitants and spouses should be identical in tax law is too radical (Lorio, 1980). However, a rational way out seems to be even a partial easing of fiscal burdens in favor of informal partners. For example, if extending tax exemptions on inheritance and endowment tax, then it may be worth giving them more favorable tax rates.

The source of some complications in tax law is the assessment of the situation of concubines involved in homosexual relationship. However, it appears that no modification of tax law is necessary in this respect. In the light of administrative court decisions, tax liability also covers cohabitants from same-sex relationships. There are many indications that such an interpretation will persist over time.

However, there is a need to regulate other issues referred to in this study. Firstly, the legislature should consider granting cohabitants the right to pay tax levied for their partners regardless of the amount of tax. Secondly, the concubinage must be regulated by the rules governing the tax procedure so that an employee of the tax authority is exempted from the hearing any case concerning his partner.

Finally, it is worth noting that the future of informal partnerships will largely depend on whether a special law on this issue is passed. Perhaps in Poland, along the lines of some countries, legislation will be adopted that will not only allow the registration of cohabitation (from this very moment it is going to be a formal confirmation of the existence of a partnership), but will also regulate many other matters, e.g. property relations, succession, etc. The adoption of such a legal act would also have a major impact on the situation of cohabitants in tax law.

\section{References}

Barlow, A. (2004). Regulation of cohabitation, changing family policies and social attitudes: A Discussion of Britain Within Europe. Law \& Policy, 26(1), 57-86. https://doi.org/10.1111/ j.0265-8240.2004.00163.x

Daniluk, P. (2015). Wspólne pożycie jako pojęcie karnoprawne [Cohabitation as a concept of criminal law]. Prokuratura i Prawo, 6, 5-27.

Dziemianowicz, R. (2019). Tax policy in OECD countries in 2007-2016: Trends and challenges. Ekonomia i Prawo, 18(4), 425-440.

Fox, E. (2017). Do taxes affect marriage? Lessons from history (NYU Law and Economics Working Paper No. 17-15). NYU Center for Law, Economics and Organization, 2-51. https://doi.org/10.2139/ ssrn.2988559

Garlicki, L. (2019). Związki monoseksualne a prawa człowieka - kształtowanie się europejskiego standardu? [Monosexual relationships and human rights - shaping the European standard?]. Przegląd Konstytucyjny, 2, 5-15.

Hahlo, H. H. (1972). The law of concubinage. South African Law Journal, 89(3), 321-332.

Herring, J. (2014). Family law: A very short introduc- 
tion. Oxford University Press.

Jaworski, S. (2012). Prawne aspekty konkubinatu [Legal aspects of cohabitation]. Monitor Prawniczy, 21, 1167-1174.

Kędzierska-Szczepaniak, A. (2015). Rozwiązania prorodzinne $\mathrm{w}$ podatku dochodowym od osób fizycznych na przykładzie Francji i Polski [Family-friendly solutions in personal income tax on the example of France and Poland]. Economics and Management, 7(1), 200-215. https://doi. org/10.12846/j.em.2015.01.13

Knauer, N. J. (1998). Heteronormativity and federal tax policy. West Virginia Law Review 101(1), 129234. https://researchrepository.wvu.edu/wvlr/ vol101/iss1/6

Lorio, K. (1980). Concubinage and its alternatives: Proposal for more perfect union. Loyola Law Review, 26(1), 1-30.

Małecka, E. (2005). Podatek dochodowy jako regulator dochodów osób fizycznych w Polsce

[Income tax as an income regulator of natural persons in Poland]. Ruch Prawniczy, Ekonomiczny i Socjologiczny, 67(2), 133-153. http://hdl.handle. net/10593/6813

Martin, C., \& Thery, I. (2001). The PACS and marriage and cohabitation in France. International Journal of Law, Policy and the Family, 15(1), 135-158. https://doi.org/10.1093/lawfam/15.1.135

Mazur, M. (1997). Konkubinat w orzecznictwie Sadu Najwyziszego [Cohabitation in the jurisprudence of the Supreme Court]. Palestra, 41(1-2), 32-54.

Nowak, I. (2017). Małżeństwo a związki partnerskie w świetle wybranych regulacji polskiego prawa podatkowego [Marriage and partnerships in the light of selected regulations of Polish tax law]. Kwartalnik Prawa Podatkowego, 3, 55-83.

Panek, M. A. (2018). Kształtowanie opodatkowania w podatku od spadków i darowizn [Formation of taxation in the inheritance and gift tax]. Nieruchomości, 9, 26-31.

Pawliczak, J. (2020). Regulacje prawne związków partnerskich w ustawodawstwie polskim oraz Unii Europejskiej [The Paths to Marriage Equality (30 Years after Institutionalization of Partnerships). Państwo i Prawo, 4, 3-23.

Rekas, M. (2015). Tax policy tools as an element of pro-family policy in France and in Germany recommendations for Poland. Ekonomia i Prawo, 14(1), 7-18.

Ryznar, M., \& Stępień-Sporek, A. (2019). Cohabitation worldwide today. Georgia State University Law Review, 35(2), 299-328.
Siostrzonek-Sergiel, A. (2015). Kilka uwag na temat zakresu konstytucyjnej ochrony rodziny

[A few remarks on the scope of constitutional family protection]. Monitor Prawniczy, 23, 1254-1258.

Skuza, D. (2020). Regulacje prawne związków partnerskich w ustawodawstwie polskim oraz Unii Europejskiej [Regulations on concubinage in the Polish and the European Union legislation]. Przeglad Prawa Publicznego, 7-8, 110-122.

Sosnowski, M. (2012). Realizacja zasady sprawiedliwego opodatkowania w podatku dochodowym od osób fizycznych [Implementation of the principle of fair taxation in personal income tax]. Research Papers of Wrocław University of Economics, 247, 345-358.

Stojanowska, W. (1988). Poland: Cohabitation. Journal of Family Law, 27(1),2 75-280.

Święch, K. (2009). Kumulacja dochodów rodziny jako element polityki podatkowej [Cumulation of family revenue as an element of tax policy]. Toruński Rocznik Podatkowy, 164-165.

Szczepańska, I. (2013). Rozwiązania o charakterze prorodzinnym w polskiej konstrukcji podatku dochodowego od osób fizycznych nieprowadzących działalności gospodarczej [Family-friendly solutions in the Polish income tax from natural persons not conducting economic activity]. Iusnovum, 7(2), 143-172.

Szlęzak, A. (1991). Cohabitation without marriage in Poland. International Journal of Law and the Family, 5(1), 1-12. https://doi.org/10.1093/law$\mathrm{fam} / 5.1 .1$

Tărchilă, P. (2017). The institution of the civil partnership. AGORA International Journal of Juridical Sciences, 2017(1), 27-32. https://doi.org/10.15837/ aijjs.v11i1.3016

Zaborowska, B. (2015). Próby uregulowania statusu związku partnerskiego $\mathrm{w}$ prawie polskim [Attempts to regulate the status of a partnership in the Polish law]. Edukacja prawnicza, 4, 30-34. 